U.S DEPARTMENT OF THE INTERIOR

U.S. GEOLOGICAL SURVEY

\title{
Record Extension and Streamflow Statistics for the Pleasant River, Maine
}

Water-Resources Investigations Report 99-4078

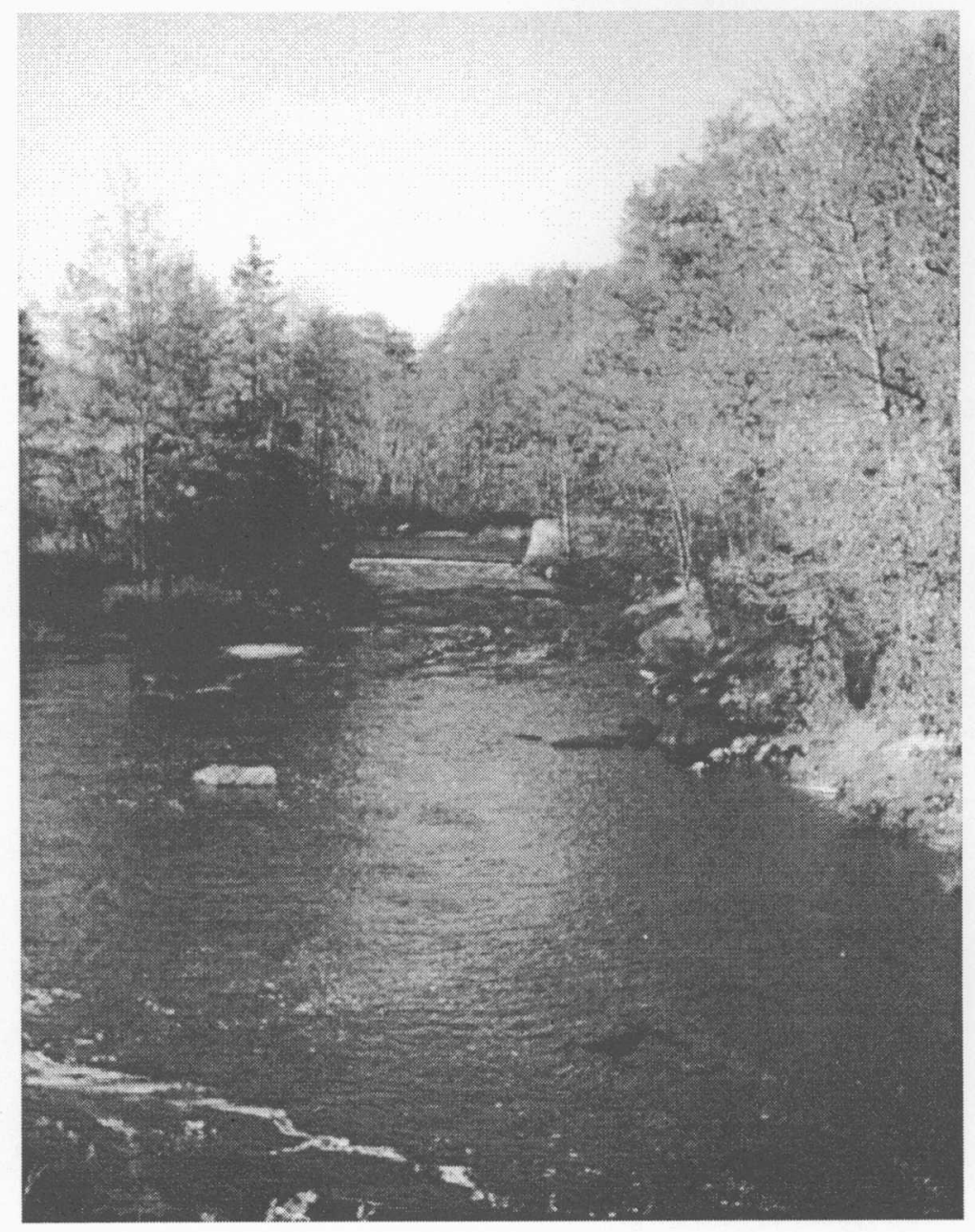

Prepared in cooperation with the MAINE STATE PLANNING OFFICE

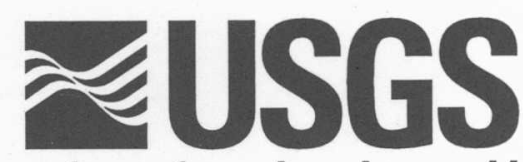

science for a changing world 
Cover Photograph. Pleasant River near Epping, Maine at site of streamgaging station. (Photograph by W. Nichols) 


\section{Record Extension and Streamflow Statistics for the Pleasant River, Maine}

By Joseph P. Nielsen

U.S. GEOLOGICAL SURVEY

Water-Resources Investigations Report 99-4078

Prepared in cooperation with the

MAINE STATE PLANNING OFFICE

Augusta, Maine 


\section{U.S. DEPARTMENT OF THE INTERIOR BRUCE BABBITT, Secretary}

\section{U.S. GEOLOGICAL SURVEY}

Charles G. Groat, Director

The use of firm, trade, and brand names in this report is for identification purposes only and does not constitute endorsement by the U.S. Geological Survey.

For additional information write to:

District Chief

U.S. Geological Survey

26 Ganneston Drive

Augusta, ME 04330
Copies of this report can be purchased from:

\author{
U.S. Geological Survey \\ Information Services \\ Box 25286 \\ Federal Center \\ Denver, CO 80225
}




\section{CONTENTS}

Abstract.
Introduction
Physical Setting
Analysis of Existing Data
Streamflow Record Extension
Application of Record Extension
Index Station Selection
References Cited.

\section{FIGURES}

1. Map showing study area and location of streamgaging stations used in the analysis .....

2. Graph showing median streamflows for the Pleasant River near Epping, Maine, using the historical period of record, 1980-91

3. Graph showing distribution of daily mean streamflow for the Narraguagus River at Cherryfield, Maine

4. Graph showing correlation of daily mean streamflow between Pleasant and Narraguagus Rivers

5-16. Graphs showing monthly flow-duration curves for extended and historical period of record, and monthly flow-duration statistics based on extended period of record, March 1948 through September 1998, for Pleasant River near Epping, Maine.

17. Graph showing flow-duration curves for extended and historical period of record, and flow-duration statistics based on extended period of record, March 1948 through September 1998, for Pleasant River near Epping, Maine

\section{TABLES}

1. Unregulated streamgaging stations in eastern Maine with more than 10 years of record ....

2. Median streamflows for historical and record-extended periods for the Pleasant River near Epping

\section{CONVERSION FACTORS}

\begin{tabular}{rll}
\hline Multiply & By & To obtain \\
\hline cubic foot per second $\left(\mathrm{ft}^{3} / \mathrm{s}\right)$ & 0.02832 & cubic meter per second \\
foot $(\mathrm{ft})$ & 0.3048 & meter \\
inch (in.) & 25.4 & millimeter \\
inch per year (in/yr) & 25.4 & millimeter per year \\
mile $(\mathrm{mi})$ & 1.609 & kilometer \\
square mile $\left(\mathrm{mi}^{2}\right)$ & 2.59 & square kilometer \\
\hline
\end{tabular}





\title{
Record Extension and Streamflow Statistics for the Pleasant River, Maine
}

\author{
by Joseph P. Nielsen
}

\section{ABSTRACT}

Historical streamflow data for the Pleasant River are limited to 11 years (from 1980 to 1991) at the U.S. Geological Survey streamgaging station near Epping. Analysis of these data in conjunction with flow data from other nearby stations indicates that the 11 years of record for the Pleasant River may not be representative of longer-term conditions in the basin. A correlation between the historical streamflows from the Pleasant River station and at the nearby station on the Narraguagus River at Cherryfield provides a means of extending the record at the Pleasant River station, increasing the period of record on the Pleasant River from 11 to 51 years. When used to calculate new streamflow-duration statistics, the extended record shows significant differences from the original 11 years of record, particularly during the summer months. The August median streamflow, an important statistical measure for fisheries habitat, changed from 50 cubic feet per second prior to the record extension, to 35 cubic feet per second after the record extension.

\section{INTRODUCTION}

In 1997, the State of Maine developed a conservation plan for Atlantic salmon in seven rivers in Maine (Maine Atlantic Salmon Task Force, 1997). As part of its implementation, the plan called for the development of total water use management plans for each of the river basins to balance the needs of agriculture with those of salmon. These plans, once developed, will set limits on water withdrawals from the river basins, one of which is the Pleasant River basin in eastern Maine. Until the plan for the Pleasant River basin is completed, interim limits, which are subject to annual review, are being used.
The only source of long-term hydrologic data in the Pleasant River basin on which to base withdrawal limits is a discontinued U.S. Geological Survey (USGS) streamgaging station on the Pleasant River near Epping (station 01022260), which was operated from August 1980 through September 1991. Analysis of the data for this station in conjunction with data for other nearby stations, however, suggests that the 11 years of record at the station is not representative of longer-term hydrologic conditions in the basin, and that summer discharges in particular may be biased high (M. Loiselle, Maine Geological Survey, written comm., 1998). If this is the case, water-resources managers risk making poor decisions in balancing the needs of salmon and agriculture.

This report describes a study done by the USGS, in cooperation with the Maine State Planning Office, to analyze the streamflow record at the Pleasant River station. The analysis included (1) an assessment of possible bias in the historical streamflow record, (2) extension of the record to a longer period to reduce any bias, and (3) estimation of streamflow statistics from the extended streamflow record for the station.

\section{PHYSICAL SETTING}

The Pleasant River basin is in eastern Maine along the coast of the Atlantic Ocean (fig. 1). Draining an area of $126 \mathrm{mi}^{2}$, the river flows predominately from north to south beginning at the top of Pleasant Mountain (elevation 1,374 ft) in Devereaux Township. The center of the basin is dominated by the Great Heath, a large raised bog with an area of approximately $7 \mathrm{mi}^{2}$. The basin is bounded to the east by the Machias River basin and to the West by the Narraguagus River basin. Largely unsettled, the basin is made up primarily of forest, blueberry barrens, and heath. The average 


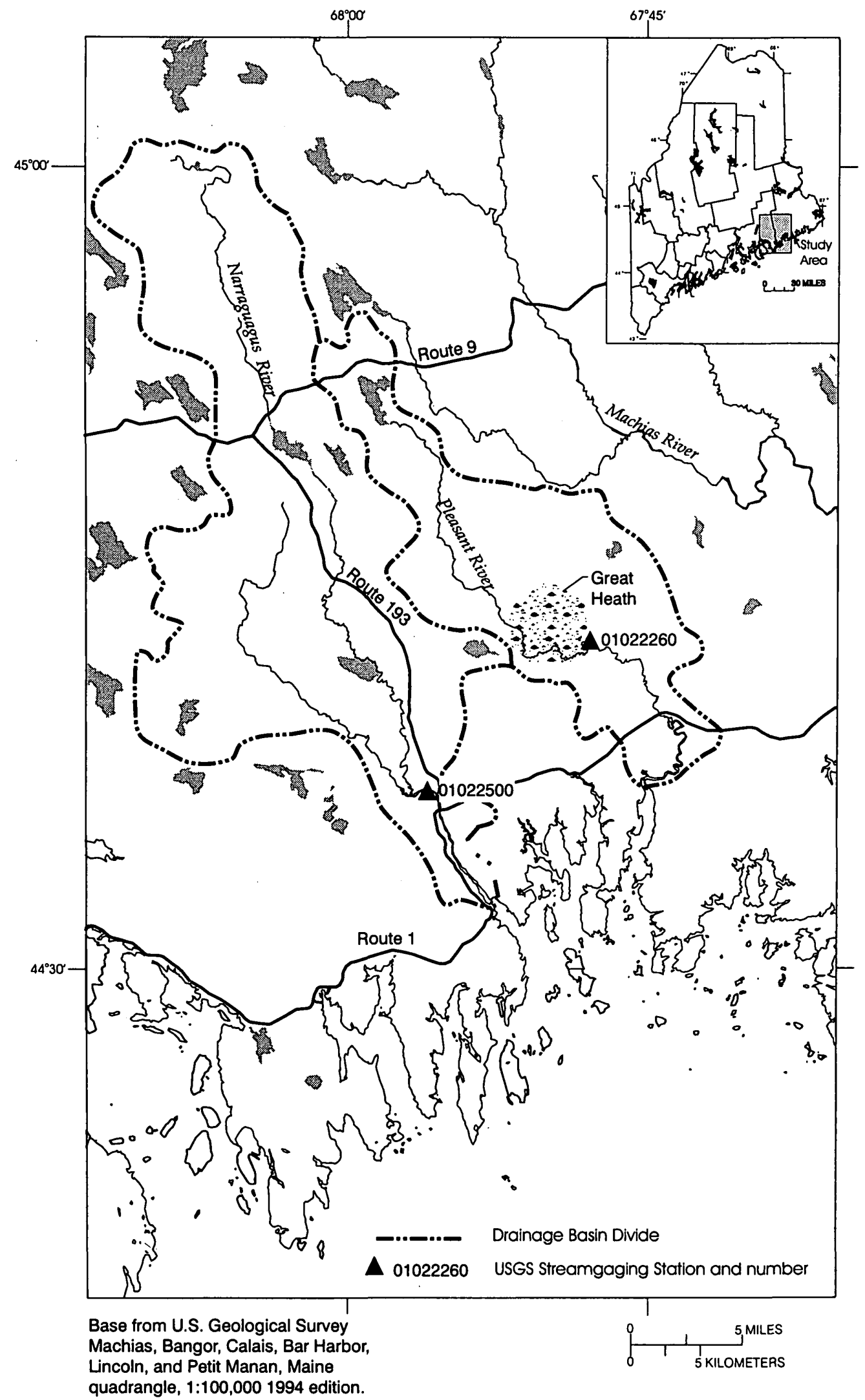

Figure 1. Study area and location of streamgaging stations used in the analysis. 
annual temperature is $42^{\circ} \mathrm{F}$ and ranges from an average of $18^{\circ} \mathrm{F}$ in January to $64^{\circ} \mathrm{F}$ in July (U.S. Department of Commerce, National Oceanic and Atmospheric

Administration, 1996). The average annual precipitation is 49 in. and is fairly evenly distributed throughout the year.

Flow in the Pleasant River, as measured by the discontinued USGS streamgaging station near Epping immediately below the Great Heath, shows a seasonal distribution common in Maine (fig. 2). High flows typically occur in early spring and late fall, and low flows generally occur in the summer, and to a lesser extent, in mid-winter.

\section{ANALYSIS OF EXISTING DATA}

To determine if the existing 11 years of data at the Pleasant River station are representative of longerterm historical conditions, the flow data from this station were analyzed in conjunction with data from the station on the Narraguagus River at Cherryfield (station 01022500). This latter station was chosen for the analysis because (1) the Narraguagus River basin adjoins the Pleasant River basin, (2) the period of record at the
Narraguagus River station is coincident with the entire period of record at the Pleasant River station, and (3) the Narraguagus River station has a much longer period of record (51 years).

In the analysis, monthly median streamflows at the Narraguagus River station for the years of data corresponding to the period of record at the Pleasant River station (1980-91) were tested against the monthly median streamflows for the years not coincident with the period of record at the Pleasant River station (194879 and 1992-98). Using the rank-sum test at a significance level of 10\% (Helsel and Hirsch, 1992), the months of January, August, and September have significantly different median values.

As a second step, pairs of boxplots of daily mean streamflow at the Narraguagus River station were developed for each month in order to compare the distribution of streamflow for the entire period of record with the distribution for the period of record coincident with the period of record at the Pleasant River station (fig. 3). The months of January, August, and September again stand out as showing considerable difference between the two periods.

Both analyses indicate bias in certain months when using flow data from the period of record of the

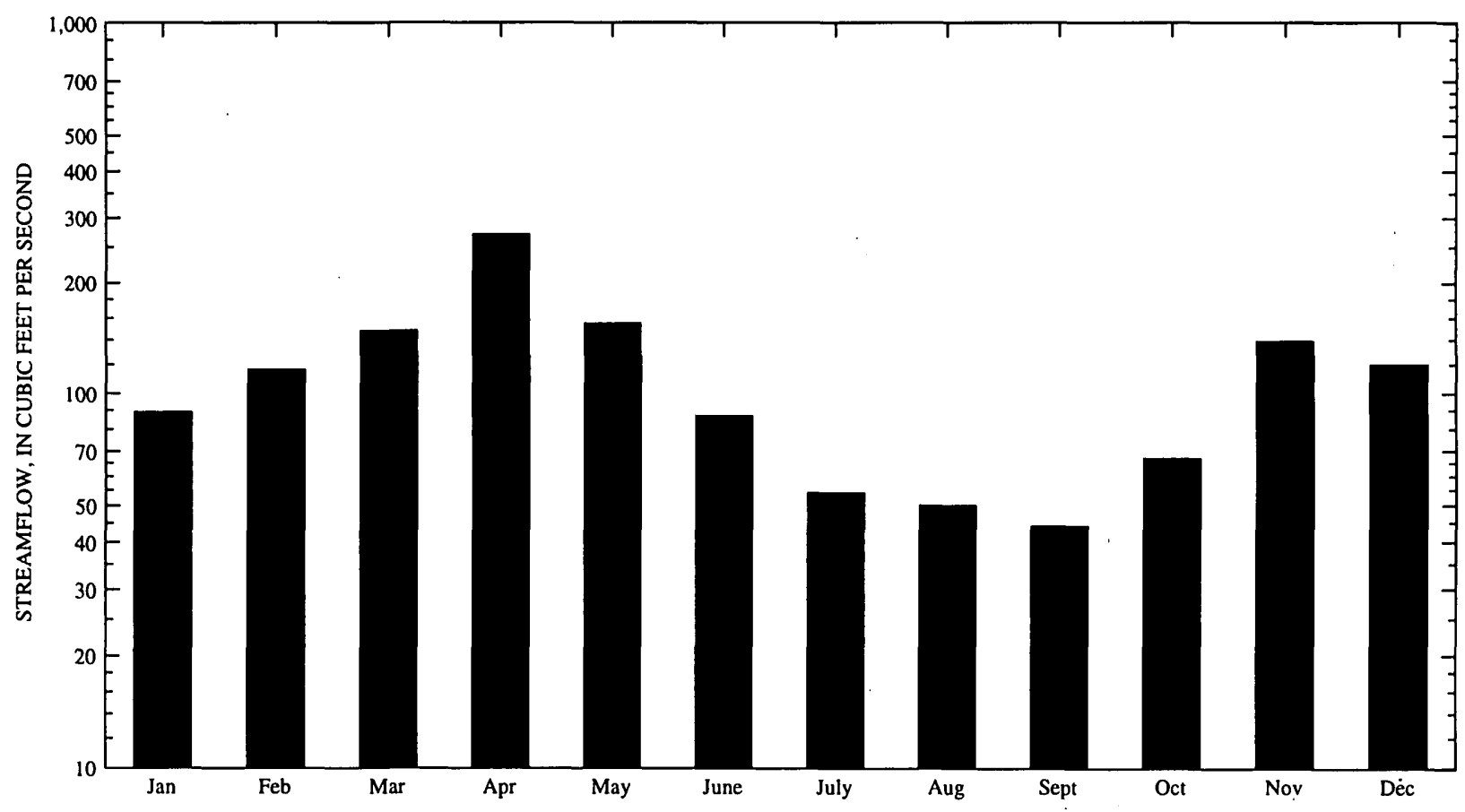

Figure 2. Median streamflows for the Pleasant River near Epping, Maine using the historical period of record, 1980-91. 
Pleasant River station. The bias shown in August is particularly significant because the August median flow is used by the U.S. Fish and Wildlife Service (USFWS) (1981) as the recommended minimum streamflow for summertime maintenance of habitat for biota. Overestimation of the August median flow, as is indicated by the statistical tests, might lead to more strict limits on water withdrawal than that intended by the USFWS policy.

\section{STREAMFLOW RECORD EXTENSION}

Record extension is a technique of extending the historical record at a streamgaging station through a correlation between that station and a longer-term index station. The correlation is used to estimate streamflow at the short-term station from the known streamflow at the index station. The record-extension technique is commonly used to improve statistical measures of streamflow at the short-term station by reducing error and(or) bias, or as part of a larger study of many stations for which a common reference period of analysis is desired (Ries, 1994). Several methods of streamflow record extension have been proposed or used in the past, including graphical-correlation (Searcy, 1959) and linear regression (Hirsch, 1982). The method used in this study is known as MOVE.1 (Maintenance Of Variance-Extension, type 1) or the Line of Organic Correlation (Helsel and Hirsch, 1992). It was first used as a means of record extension by Hirsch (1982). The MOVE.1 technique produces streamflow estimates at the short-term station with a statistical distribution similar to that expected if the streamflow had actually been measured (Helsel and Hirsch, 1992, p. 277) and will thus correctly estimate the probability of extreme high or low streamflow. Simple linear regression, by comparison, will always underestimate the occurrence of extreme events.

\section{Record Extension Technique}

The MOVE.1 technique assumes that a linear relation exists between the concurrent flows at the short and long-term stations. Because streamflow data are highly skewed, a log transformation is commonly done in order to linearize the data. Once linearity is con-

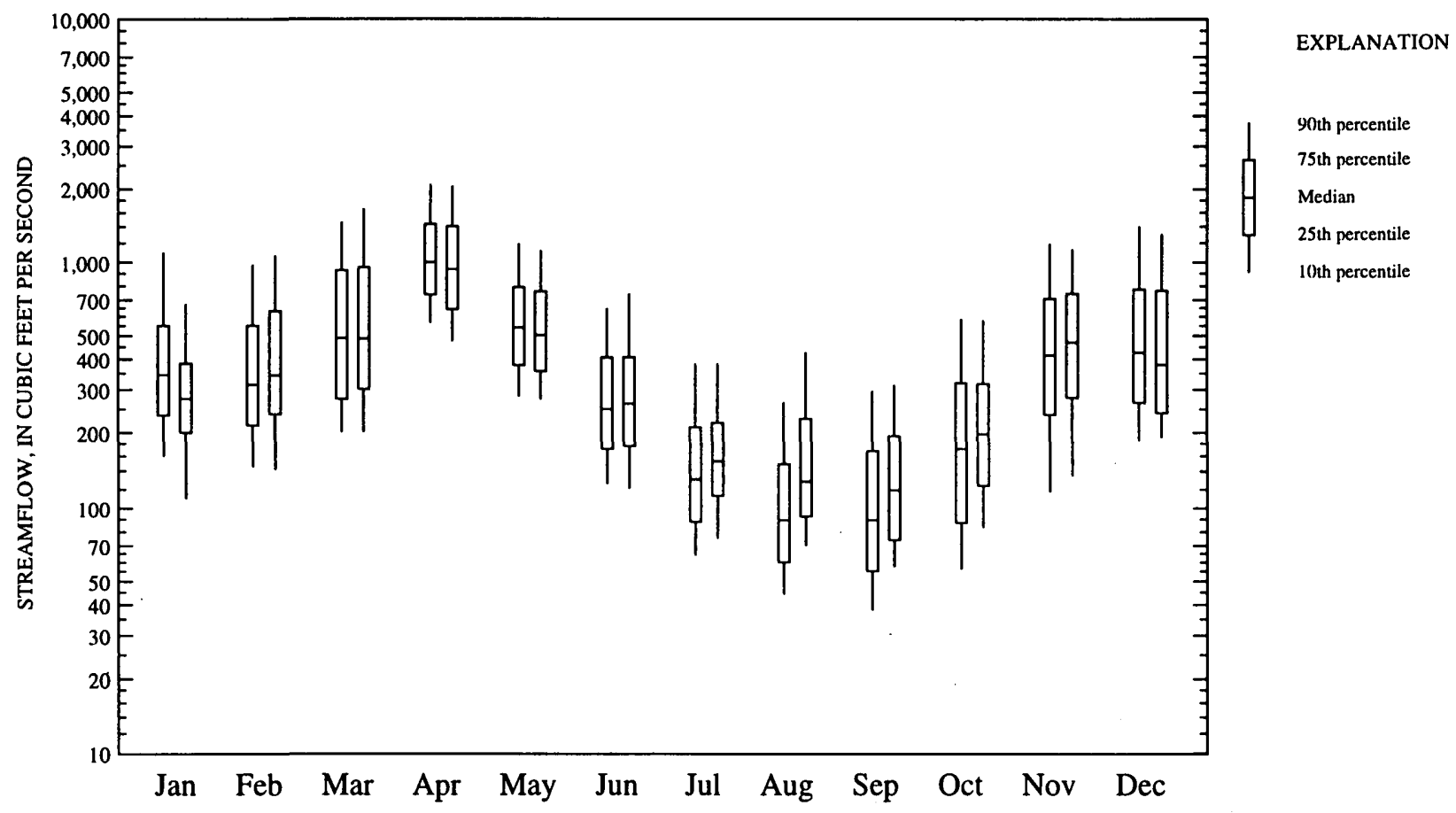

Figure 3. Distribution of daily mean streamflow for the Narraguagus River at Cherryfield, Maine. [The first box of each pair is for the period of record March 1948 to September 1998. The second box is for the period August 1980 to September 1991.] 
firmed, the means $(\bar{Y}$ and $\bar{X})$ and standard deviations $\left(S_{y}\right.$ and $S_{x}$ ) of the logs of the concurrent streamflow data are calculated. The MOVE. 1 equation is then written as follows:

$$
\hat{Y}_{i}=\bar{Y}+\frac{S_{y}}{S_{x}}\left(X_{i}-\bar{X}\right) .
$$

Estimates of discharge for the short-term site are computed by entering known logarithms of the discharge at the long-term site $\left(X_{i}\right)$ into the equation and then exponentiating the estimates $\left(\hat{Y}_{i}\right)$ from logarithms back into original units.

\section{Application of Record Extension}

Application of the MOVE.1 record extension technique involves choosing the most appropriate longterm index station, computing the necessary terms in the MOVE. 1 equation, and calculating the record extended streamflow estimates. The application of this technique to the Pleasant River is described in the following sections.

\section{Index Station Selection}

The long-term index station used in the record extension must satisfy several criteria, including that it be unregulated, have a portion of its period of record coincident with that at the short-term station, and have a substantially longer period of record than the short term station. In addition, the concurrent daily streamflows for the short and long-term stations must plot linearly in log space and be highly correlated.The only station meeting these criteria in eastern Maine is the Narraguagus River at Cherryfield (table 1), primarily because the Narraguagus River station is the only available station with over two years of overlapping record with the Pleasant River station.

The period of record at the Narraguagus River station completely contains the 11 years of record at the Pleasant River station, but in addition includes another 40 years of record from both prior to the start of, and after the discontinuation of, the Pleasant River station. The Narraguagus River drains the watershed immediately west of the Pleasant River basin and has similar watershed characteristics. Due to the presence of the Great Heath, however, the percentage of the basin in wetlands is substantially higher in the Pleasant River basin (26.7\%), than in the Narraguagus (15.0\%) (Hodgkins, 1999).

A graph of concurrent daily mean discharge in log space for the Pleasant and Narraguagus Rivers (fig. 4), and the computed correlation coefficient of 0.97 , confirm that a linear relation exists between streamflow at the two stations. A minimum correlation coefficient required for the MOVE. 1 technique has not been developed; however, similar correlation studies have used values ranging from 0.70 (Stedinger and Thomas, 1985) to 0.80 (Ries, 1994).

It is possible, however, that although a strong correlation exists between the two stations for the entire period of concurrent record, correlations might be weaker for individual months. If so, this could cause considerable error in the estimates of streamflow for those months. As a check of this, plots also were developed for each month individually and correlation coefficients were found to be between 0.90 and 0.98 . These high correlation coefficients indicate that differences in watershed characteristics between the two basins, including drainage area and percentage of basin wetlands, are either explained by the MOVE.1 equation or are not a dominant factor in the relation of streamflow at the two sites.

Table 1. Unregulated streamgaging stations in eastern Maine with more than 10 years of record

\begin{tabular}{|c|c|c|c|}
\hline $\begin{array}{c}\text { USGS } \\
\text { station } \\
\text { number }\end{array}$ & Station name & $\begin{array}{c}\text { Period } \\
\text { of } \\
\text { record }\end{array}$ & $\begin{array}{c}\text { Drainage } \\
\text { area in } \\
\text { square } \\
\text { miles }\end{array}$ \\
\hline 01021500 & $\begin{array}{c}\text { Machias River at } \\
\text { Whitneyville }\end{array}$ & $\begin{array}{l}1906-09 \\
1910-21 \\
1929-77\end{array}$ & 458 \\
\hline 01022000 & $\begin{array}{l}\text { East Machias River near } \\
\text { East Machias }\end{array}$ & $1927-58$ & 251 \\
\hline 01022260 & $\begin{array}{l}\text { Pleasant River near } \\
\text { Epping }\end{array}$ & $1980-91$ & 60.6 \\
\hline 01022500 & $\begin{array}{l}\text { Narraguagus River at } \\
\text { Cherryfield }\end{array}$ & $1948-98$ & 227 \\
\hline 01023000 & $\begin{array}{l}\text { West Branch Union } \\
\text { River near Amhearst }\end{array}$ & $\begin{array}{l}1910-19 \\
1929-79\end{array}$ & 148 \\
\hline 01024200 & $\begin{array}{l}\text { Garland Brook near } \\
\text { Mariaville }\end{array}$ & $1964-82$ & 9.79 \\
\hline
\end{tabular}




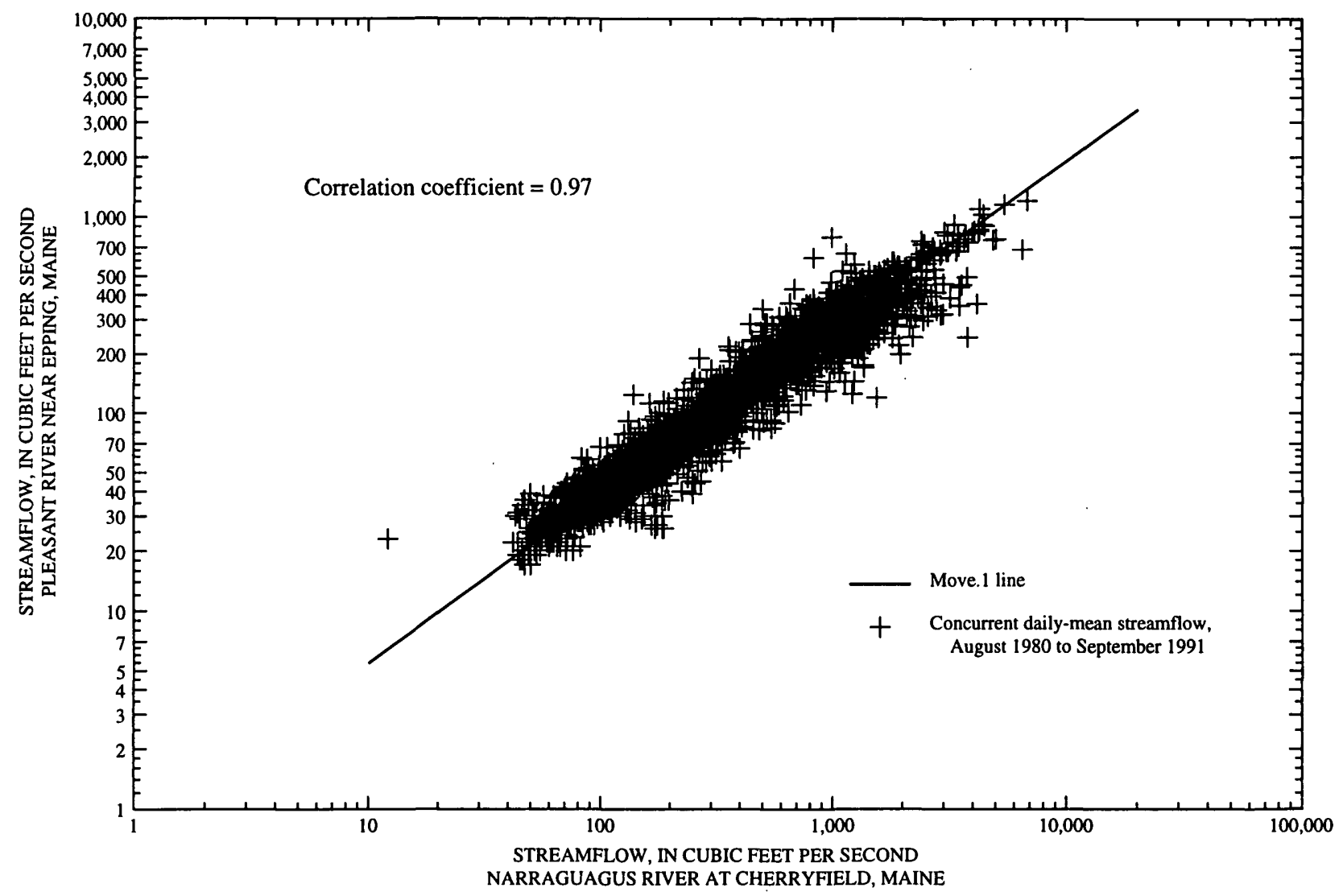

Figure 4. Correlation of daily mean streamflow between Pleasant and Narraguagus Rivers.

\section{Generation of Extended Record}

Once the Narraguagus River station was chosen as the most appropriate long-term index station, the means and standard deviations of the logarithms of the concurrent daily mean streamflows for the Narraguagus and Pleasant River stations were computed. These were then used to develop the final MOVE.1 equation:

$$
\hat{Y}_{i}=2.010+\frac{0.3389}{0.3985}\left(X_{i}-2.498\right) \text {, }
$$

which simplifies to:

$$
\hat{Y}_{i}=0.8504 X_{i}-(0.1144)
$$

where

$X_{i}$ are the logarithms of the daily mean streamflow on the Narraguagus River, and

$\hat{Y}_{i}$ are the logarithms of the estimated daily mean streamflow on the Pleasant River.
To compute estimates of streamflows at the Pleasant River station, all of the historical daily mean streamflow from the Narraguagus River station were used in the MOVE.1 equation except those for which data already existed on the Pleasant River. The estimates from the equation were then exponentiated to obtain the final extended-record estimates in original units for the Pleasant River. These estimates were then added to the historical record from the Pleasant River to obtain the final streamflows used in the computation of streamflow statistics.

\section{EXTENDED-RECORD STREAMFLOW STATISTICS}

Median streamflows for the Pleasant River are shown in table 2 for all days and by month for the period of historical record and the period of record extension. The months of January, Aưgust, and September, which were the months found to have significant bias in the historical record, show the largest percentage change in median streamflow as a result of 
the record extension. The months of March through June show the smallest percentage change in median streamflow.

Monthly flow-duration curves for the historical and extended periods of record, and flow-duration statistics for the extended record are shown in the graphs and tables in figures 5-16 at the back of this report. Similar curves for the entire record for both periods of analysis, and statistics for the entire record for the extended period are shown in figure 17. The duration curves for the entire record show that streamflows below 70 cubic feet per second, which occurred primarily during the months of July through October, were underrepresented in the historical period. Several months show very little change between the percentiles calculated from data for the historical record and those calculated on the basis of the extended record.

Table 2. Median streamflows for historical and recordextended periods for the Pleasant River near Epping

\begin{tabular}{|c|c|c|c|}
\hline \multirow[b]{2}{*}{ Period } & \multicolumn{2}{|c|}{$\begin{array}{l}\text { Median streamflow } \\
\text { in cubic feet per second }\end{array}$} & \multirow[b]{2}{*}{$\begin{array}{c}\text { Percent } \\
\text { difference }\end{array}$} \\
\hline & $\begin{array}{c}\text { Historical } \\
\text { period, August } \\
1980 \text { to Sep- } \\
\text { tember } 1991\end{array}$ & $\begin{array}{c}\text { Record- } \\
\text { extended } \\
\text { period, March } \\
1948 \text { to Sep- } \\
\text { tember } 1998\end{array}$ & \\
\hline January & 89 & 110 & +23.6 \\
\hline February & 116 & 104 & -10.3 \\
\hline March & 148 & 149 & +0.7 \\
\hline April & 270 & 276 & +2.2 \\
\hline May & 155 & 162 & +4.5 \\
\hline June & 87 & 84 & -3.4 \\
\hline July & 54 & 48 & -11.1 \\
\hline August & 50 & 35 & -30.0 \\
\hline September & 44 & 35 & -20.5 \\
\hline October & 67 & 60 & -10.4 \\
\hline November & 139 & 126 & -9.4 \\
\hline December & 120 & 133 & -10.8 \\
\hline Entire record & 96 & 99 & +3.1 \\
\hline
\end{tabular}

\section{REFERENCES CITED}

Helsel, D.R., and Hirsch, R.M., 1992, Statistical methods in water resources: Amsterdam, the Netherlands, Elsevier Science Publishers, $522 \mathrm{p}$.

Hirsch, R.M., 1982, A comparison of four streamflow record extension techniques: Water Resources Research, v. 18, no. 4., p. 1081-1088.

Hodgkins, G.A., 1999, Estimating the Magnitude of Peak Flows for Streams in Maine for Selected Recurrence Intervals: U.S.Geological Survey Water-Resources Investigations Report 99-4008, p. 21.

Maine Atlantic Salmon Task Force, 1997, Atlantic salmon conservation plan for seven Maine rivers.

Ries, K.G., III, 1994, Estimation of low-flow duration discharges in Massachusetts: U.S. Geological Survey Water-Supply Paper 2418, $50 \mathrm{p}$.

Searcy, J.K., 1959, Flow-duration curves, manual of hydrology -part 2. Low-flow techniques: U.S. Geological Survey Water-Supply Paper 1542-A, p. 1-33.

Stedinger, J.R., and Thomas, W.O., Jr, 1985, Low-flow frequency estimation using base-flow measurements: U.S. Geological Survey Open-File Report 85-95, p.21.

U.S. Department of Commerce, National Oceanic and Atmospheric Administration, 1996, Climatological data, annual summary, New England, v. 108, no. 13, $35 \mathrm{p}$.

U.S. Fish and Wildlife Service, 1981, Interim regional policy for New England stream flow recommendations: Newton Corner, MA: U.S. Fish and Wildlife Service. 
Figures 5-17: Flow-Duration Curves and Statistics 


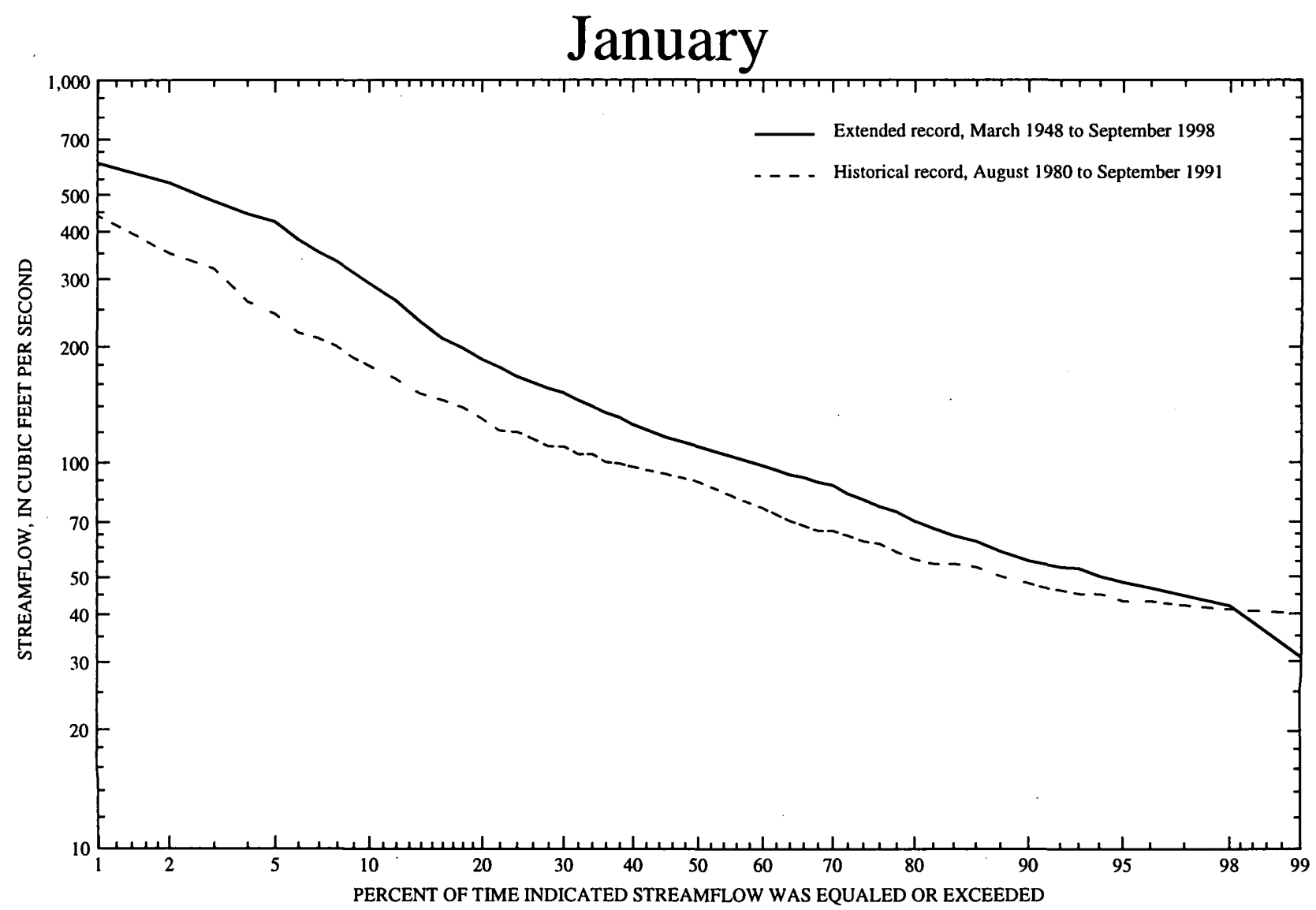

\begin{tabular}{cccc}
\hline $\begin{array}{c}\text { Percent of time } \\
\text { indicated } \\
\text { streamflow was } \\
\text { equaled or } \\
\text { exceeded }\end{array}$ & $\begin{array}{c}\text { Streamflow, in } \\
\text { cubic feet per } \\
\text { second }\end{array}$ & $\begin{array}{c}\text { Percent of time } \\
\text { indicated } \\
\text { streamflow was } \\
\text { equaled or } \\
\text { exceeded }\end{array}$ & $\begin{array}{c}\text { Streamflow, in } \\
\text { cubic feet per } \\
\text { second }\end{array}$ \\
\hline 1 & 605 & 55 & 104 \\
5 & 423 & 60 & 98 \\
10 & 292 & 65 & 93 \\
15 & 220 & 70 & 87 \\
20 & 185 & 75 & 78 \\
25 & 163 & 80 & 70 \\
30 & 152 & 85 & 64 \\
35 & 137 & 90 & 55 \\
40 & 125 & 95 & 48 \\
45 & 116 & 99 & 31 \\
50 & 110 & & \\
\hline
\end{tabular}

Figure 5. Flow-duration curves for January for extended and historical period of record (top), and flow-duration statistics for January based on extended period of record, March 1948 through September 1998 (bottom), for Pleasant River near Epping, Maine. 


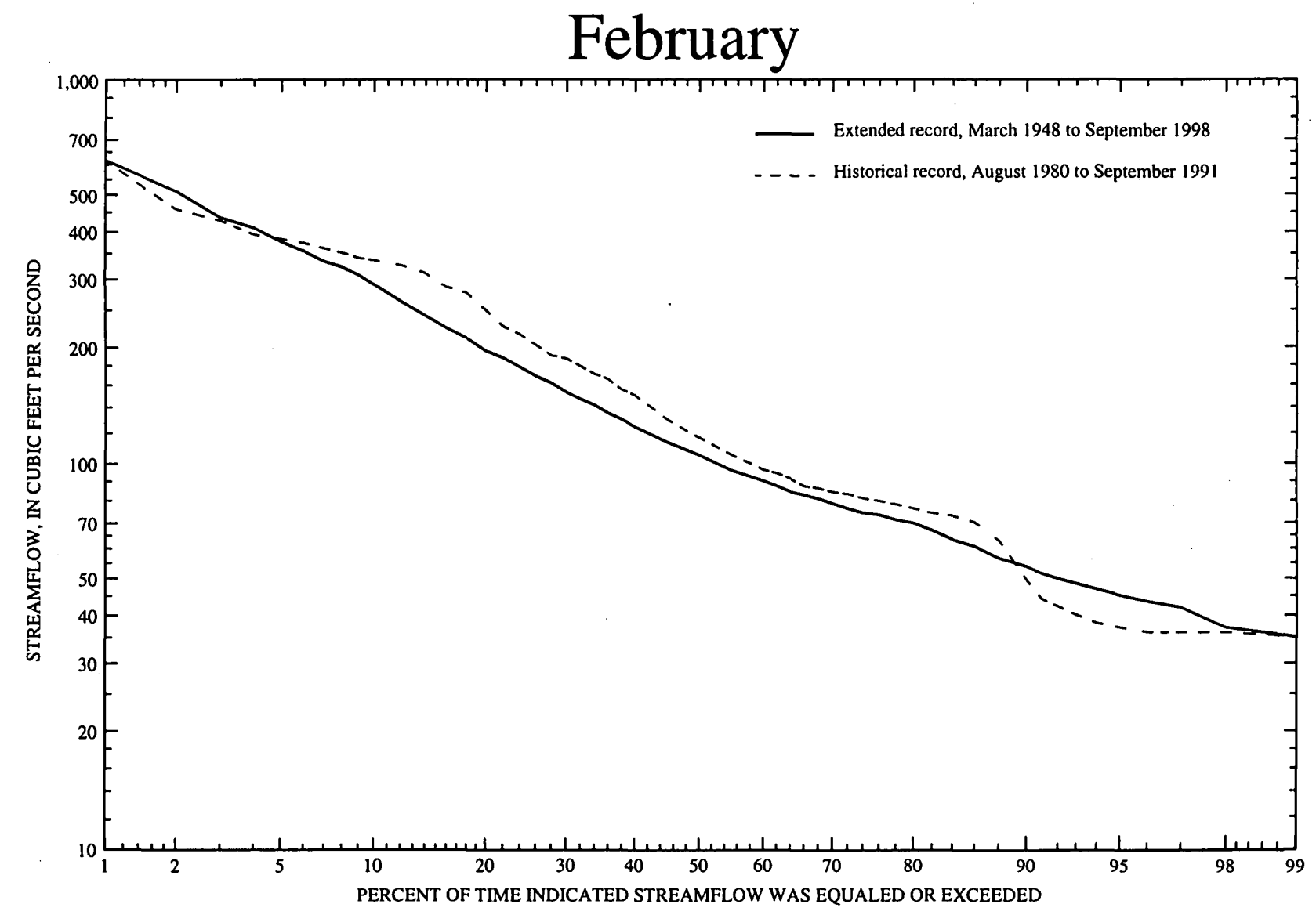

\begin{tabular}{cccc}
\hline $\begin{array}{c}\text { Percent of time } \\
\text { indicated } \\
\text { streamflow was } \\
\text { equaled or } \\
\text { exceeded }\end{array}$ & $\begin{array}{c}\text { Streamflow, in } \\
\text { cubic feet per } \\
\text { second }\end{array}$ & $\begin{array}{c}\text { Percent of time } \\
\text { indicated } \\
\text { streamflow was } \\
\text { equaled or } \\
\text { exceeded }\end{array}$ & $\begin{array}{c}\text { Streamflow, in } \\
\text { cubic feet per } \\
\text { second }\end{array}$ \\
\hline 1 & 617 & 55 & 96 \\
5 & 376 & 60 & 90 \\
10 & 290 & 65 & 84 \\
15 & 231 & 70 & 78 \\
20 & 195 & 75 & 74 \\
25 & 173 & 80 & 70 \\
30 & 153 & 85 & 61 \\
35 & 139 & 90 & 54 \\
40 & 124 & 95 & 45 \\
45 & 113 & 99 & 35 \\
50 & 105 & & \\
\hline
\end{tabular}

Figure 6. Flow-duration curves for February for extended and historical period of record (top), and flow-duration statistics for January based on extended period of record, March 1948 through September 1998 (bottom), for Pleasant River near Epping, Maine. 


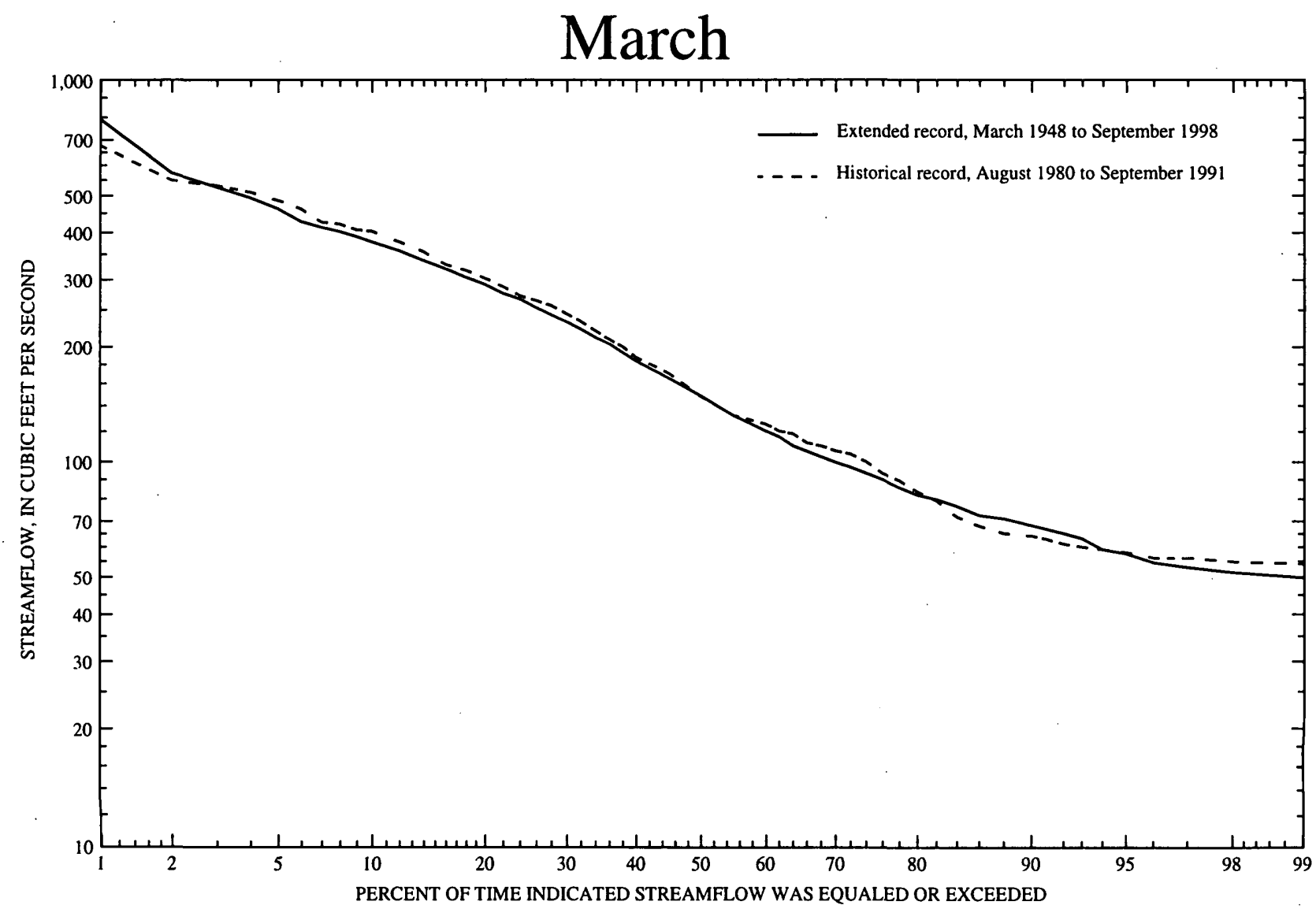

\begin{tabular}{cccc}
\hline $\begin{array}{c}\text { Percent of time } \\
\text { indicated } \\
\text { streamflow was } \\
\text { equaled or } \\
\text { exceeded }\end{array}$ & $\begin{array}{c}\text { Streamflow, in } \\
\text { cubic feet per } \\
\text { second }\end{array}$ & $\begin{array}{c}\text { Percent of time } \\
\text { indicated } \\
\text { streamflow was } \\
\text { equaled or } \\
\text { exceeded }\end{array}$ & $\begin{array}{c}\text { Streamflow, in } \\
\text { cubic feet per } \\
\text { second }\end{array}$ \\
\hline 1 & 788 & 55 & 132 \\
5 & 461 & 60 & 120 \\
10 & 377 & 65 & 109 \\
15 & 330 & 70 & 100 \\
20 & 291 & 75 & 92 \\
25 & 259 & 80 & 82 \\
30 & 232 & 85 & 75 \\
35 & 208 & 90 & 68 \\
40 & 183 & 95 & 58 \\
45 & 165 & 99 & 50 \\
50 & 149 & & \\
\hline
\end{tabular}

Figure 7. Flow-duration curves for March for extended and historical period of record (top), and flow-duration statistics for January based on extended period of record, March 1948 through September 1998 (bottom), for Pleasant River near Epping, Maine. 


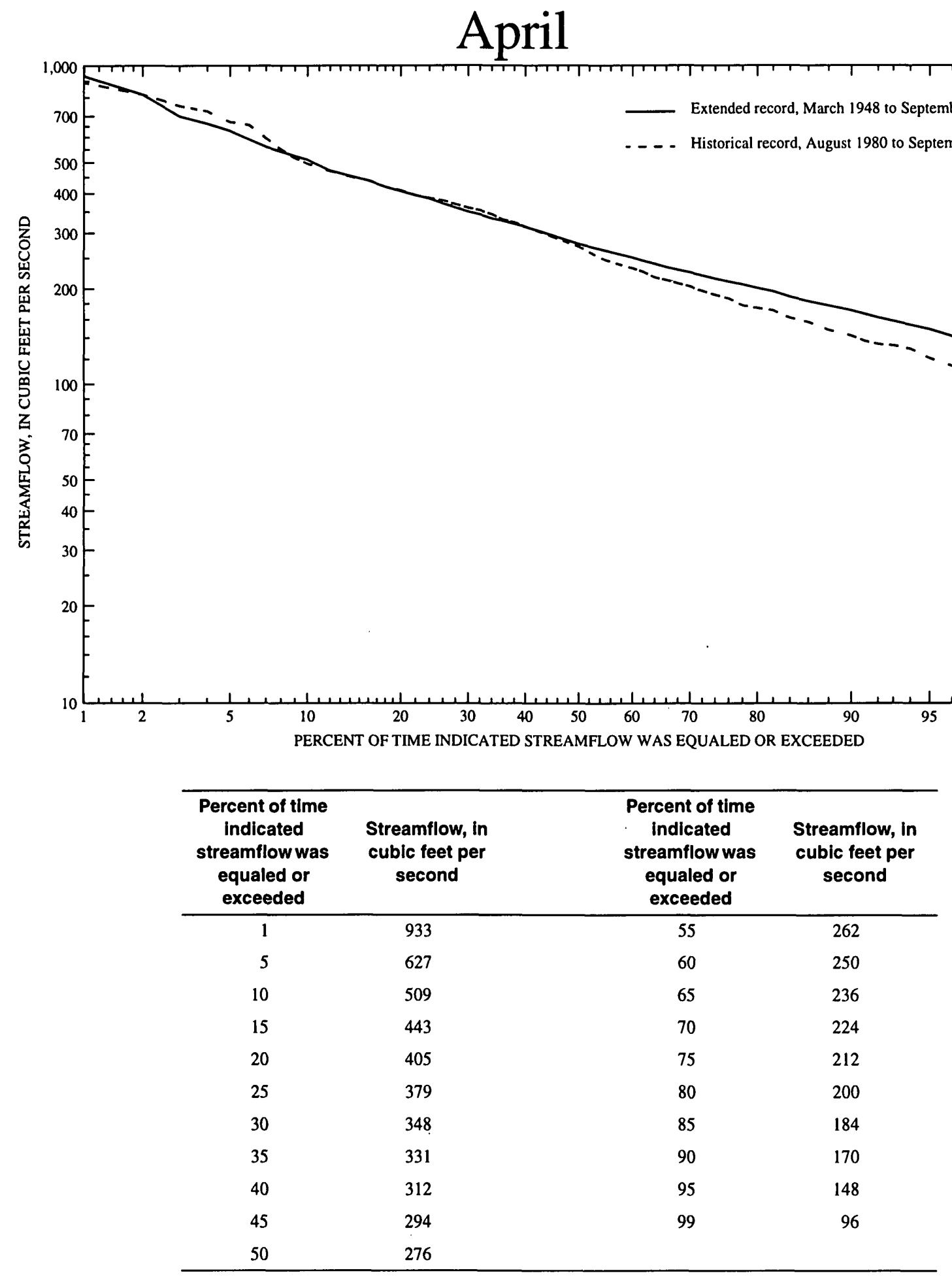

Figure 8. Flow-duration curves for April for extended and historical period of record (top), and flow-duration statistics for January based on extended period of record, March 1948 through September 1998 (bottom), for Pleasant River near Epping, Maine. 


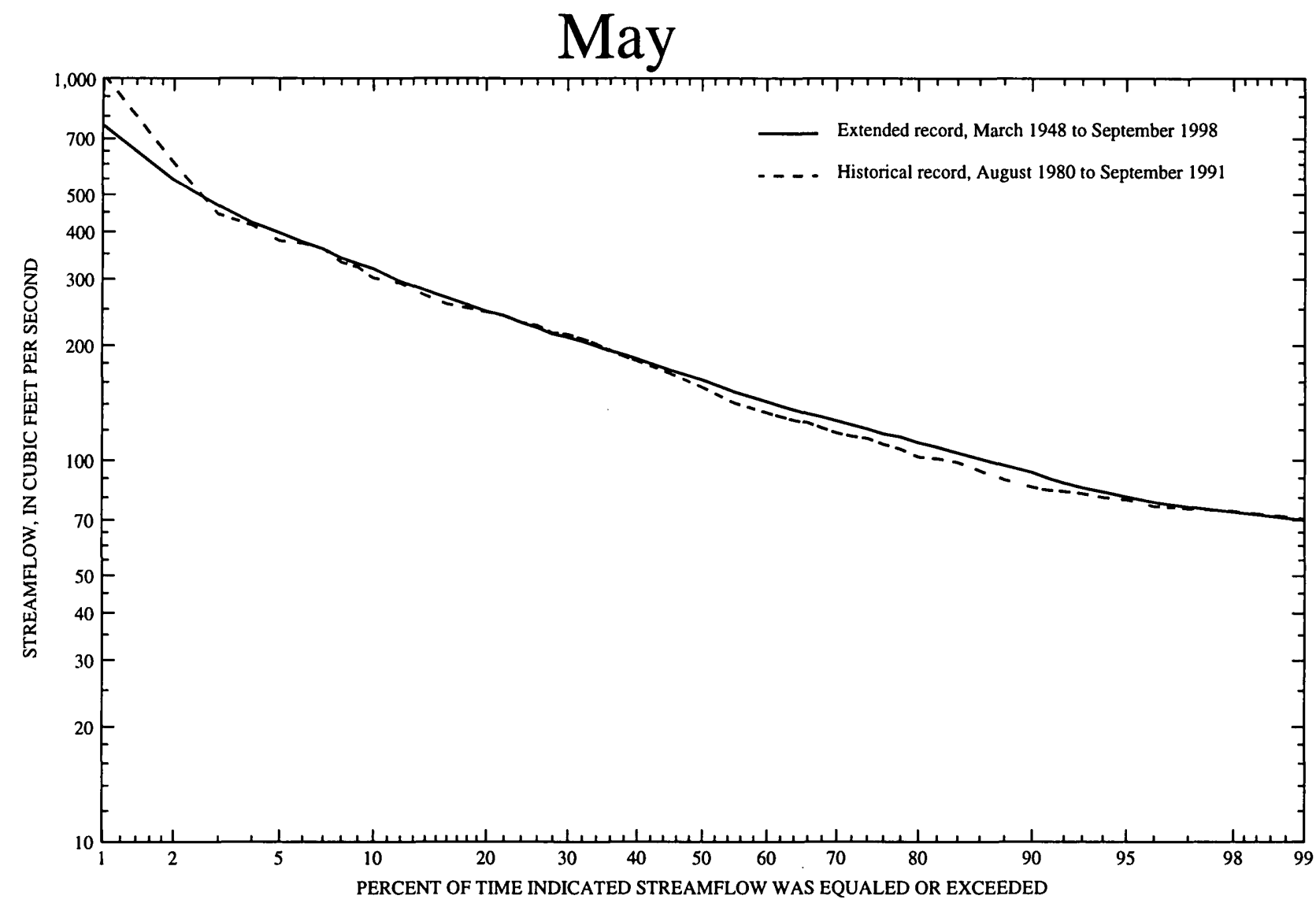

\begin{tabular}{cccc}
\hline $\begin{array}{c}\text { Percent of time } \\
\text { indicated } \\
\text { streamflow was } \\
\text { equaled or } \\
\text { exceeded }\end{array}$ & $\begin{array}{c}\text { Streamflow, in } \\
\text { cubic feet per } \\
\text { second }\end{array}$ & $\begin{array}{c}\text { Percent of time } \\
\text { indicated } \\
\text { streamflow was } \\
\text { equaled or } \\
\text { exceeded }\end{array}$ & $\begin{array}{c}\text { Streamflow, in } \\
\text { cubic feet per } \\
\text { second }\end{array}$ \\
\hline 1 & 758 & 55 & 151 \\
5 & 396 & 60 & 142 \\
10 & 319 & 65 & 134 \\
15 & 271 & 70 & 127 \\
20 & 246 & 75 & 119 \\
25 & 226 & 80 & 111 \\
30 & 210 & 85 & 103 \\
35 & 197 & 90 & 93 \\
40 & 184 & 95 & 80 \\
45 & 172 & 99 & 70 \\
50 & 162 & & \\
\hline
\end{tabular}

Figure 9. Flow-duration curves for May for extended and historical period of record (top), and flow-duration statistics for January based on extended period of record, March 1948 through September 1998 (bottom), for Pleasant River near Epping, Maine. 


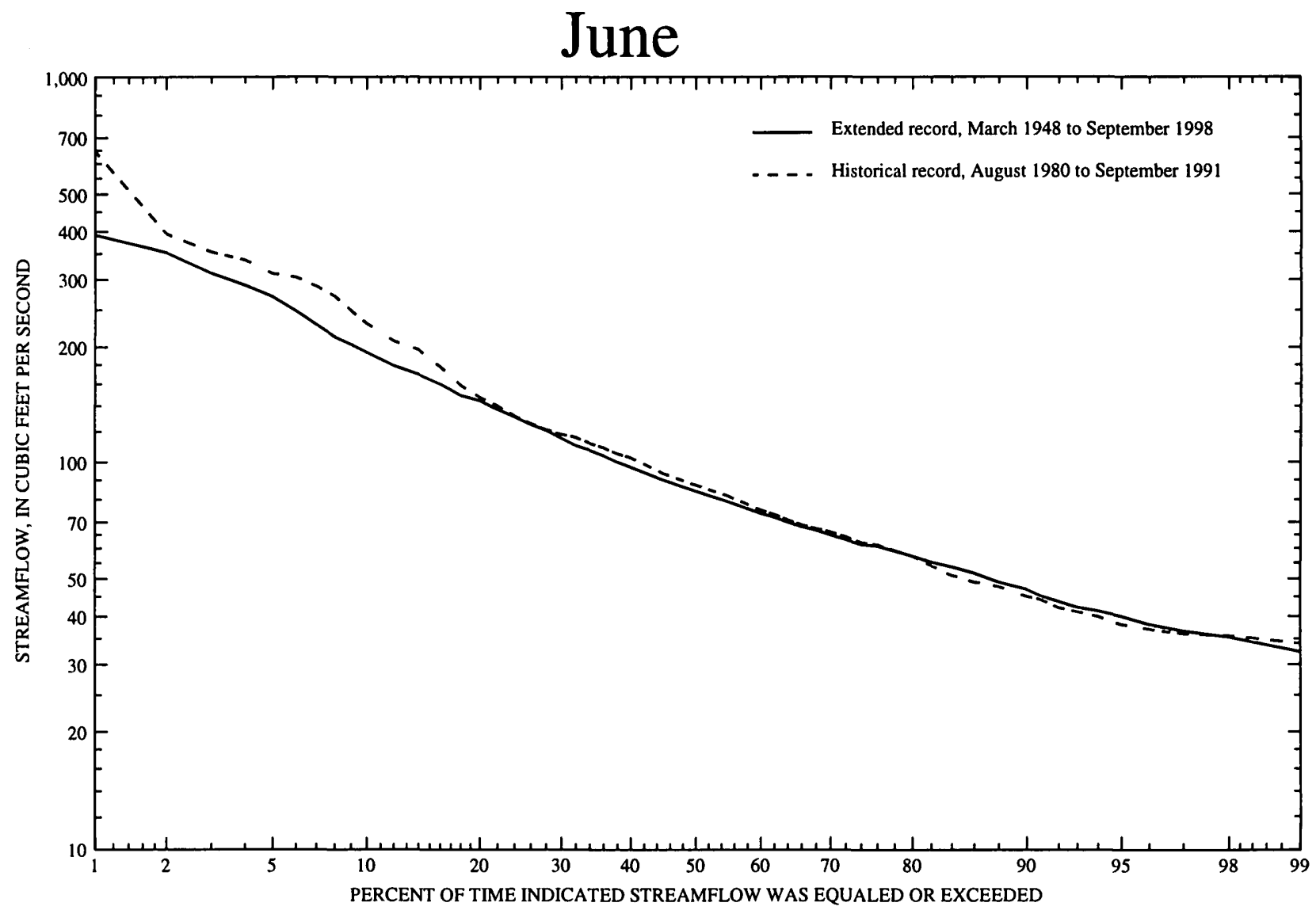

\begin{tabular}{cccc}
\hline $\begin{array}{c}\text { Percent of time } \\
\text { indicated } \\
\text { streamflow was } \\
\text { equaled or } \\
\text { exceeded }\end{array}$ & $\begin{array}{c}\text { Streamflow, in } \\
\text { cubic feet per } \\
\text { second }\end{array}$ & $\begin{array}{c}\text { Percent of time } \\
\text { indicated } \\
\text { streamflow was } \\
\text { equaled or } \\
\text { exceeded }\end{array}$ & $\begin{array}{c}\text { Streamflow, in } \\
\text { cubic feet per } \\
\text { second }\end{array}$ \\
\hline 1 & 391 & 55 & 79 \\
5 & 270 & 60 & 74 \\
10 & 194 & 65 & 69 \\
15 & 163 & 70 & 65 \\
20 & 144 & 75 & 61 \\
25 & 127 & 80 & 57 \\
30 & 115 & 85 & 53 \\
35 & 106 & 90 & 47 \\
40 & 97 & 95 & 40 \\
45 & 90 & 99 & 32 \\
50 & 84 & & \\
\hline
\end{tabular}

Figure 10. Flow-duration curves for June for extended and historical period of record (top), and flow-duration statistics for January based on extended period of record, March 1948 through September 1998 (bottom), for Pleasant River near Epping, Maine. 


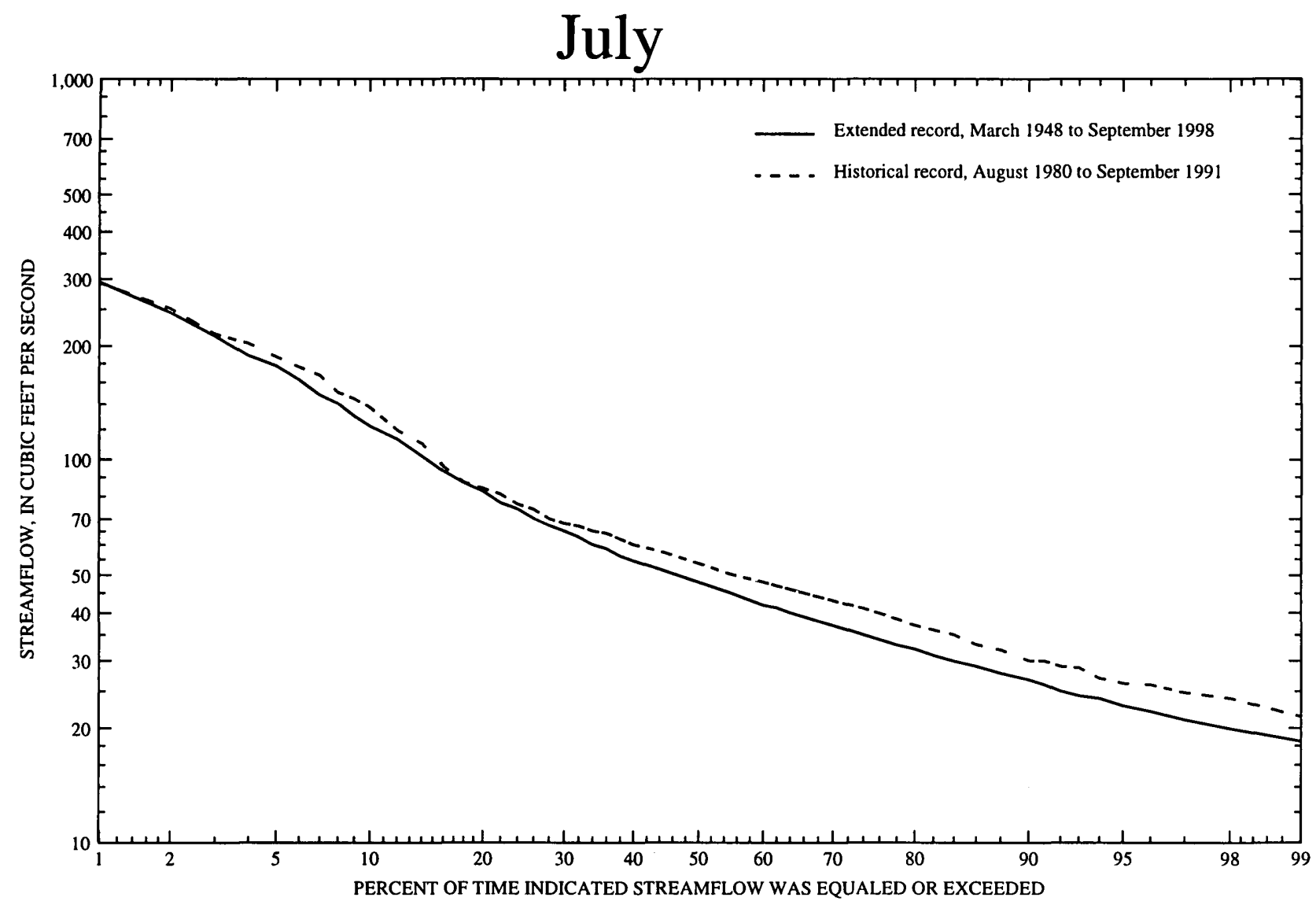

\begin{tabular}{cccc}
\hline $\begin{array}{c}\text { Percent of time } \\
\text { indicated } \\
\text { streamflow was } \\
\text { equaled or } \\
\text { exceeded }\end{array}$ & $\begin{array}{c}\text { Streamflow, in } \\
\text { cubic feet per } \\
\text { second }\end{array}$ & $\begin{array}{c}\text { Percent of time } \\
\text { indicated } \\
\text { streamflow was } \\
\text { equaled or } \\
\text { exceeded }\end{array}$ & $\begin{array}{c}\text { Streamflow, in } \\
\text { cubic feet per } \\
\text { second }\end{array}$ \\
\hline 1 & 294 & 55 & 45 \\
5 & 177 & 60 & 42 \\
10 & 122 & 65 & 39 \\
15 & 99 & 70 & 37 \\
20 & 83 & 75 & 35 \\
25 & 72 & 80 & 32 \\
30 & 65 & 85 & 29 \\
35 & 59 & 90 & 27 \\
40 & 54 & 95 & 23 \\
45 & 51 & 99 & 18 \\
50 & 48 & & \\
\hline
\end{tabular}

Figure 11. Flow-duration curves for July for extended and historical period of record (top), and flow-duration statistics for January based on extended period of record, March 1948 through September 1998 (bottom), for Pleasant River near Epping, Maine. 


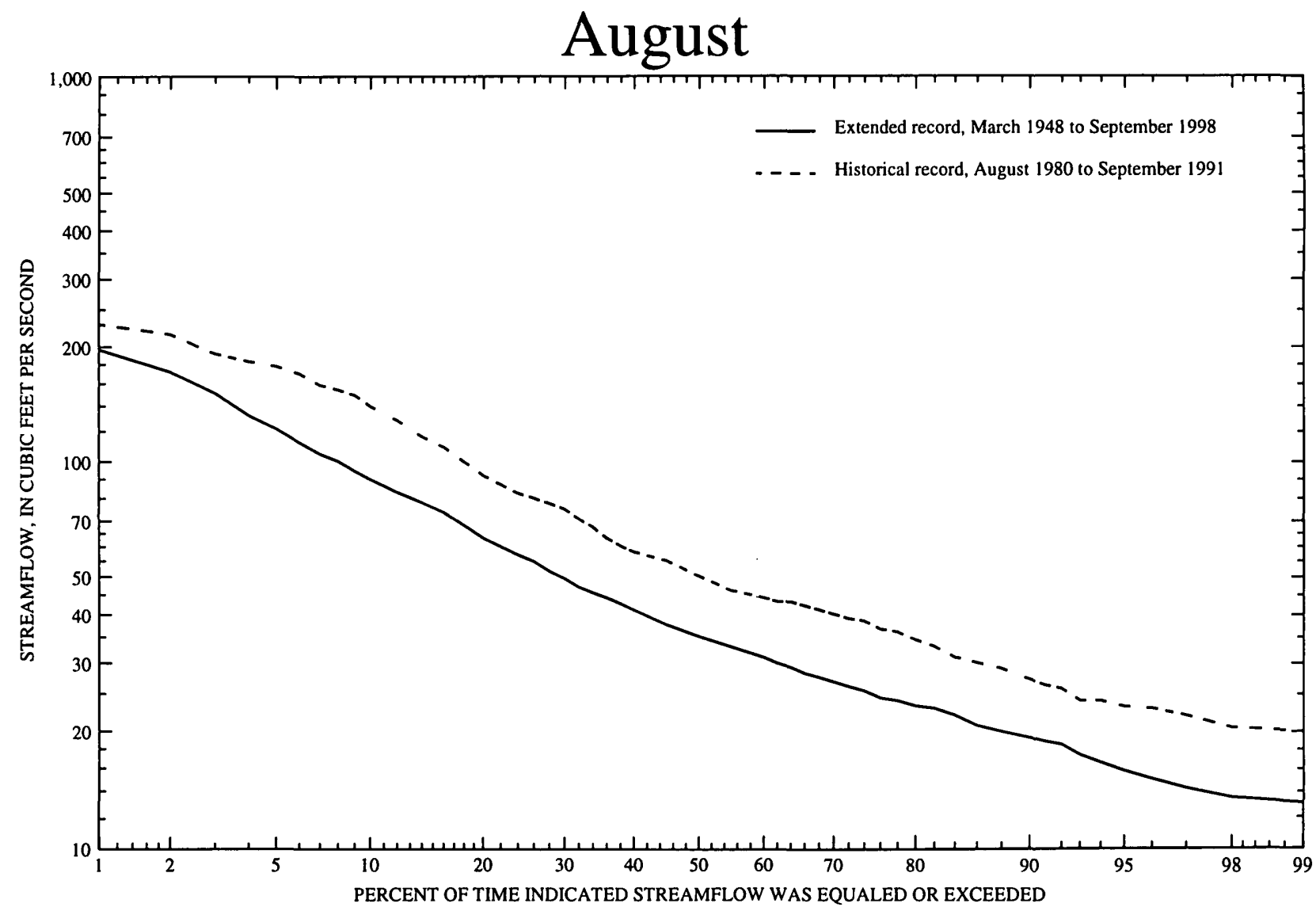

\begin{tabular}{cccc}
\hline $\begin{array}{c}\text { Percent of time } \\
\text { indicated } \\
\text { streamflow was } \\
\text { equaled or } \\
\text { exceeded }\end{array}$ & $\begin{array}{c}\text { Streamflow, in } \\
\text { cubic feet per } \\
\text { second }\end{array}$ & $\begin{array}{c}\text { Percent of time } \\
\text { indicated } \\
\text { streamflow was } \\
\text { equaled or } \\
\text { exceeded }\end{array}$ & $\begin{array}{c}\text { Streamflow, in } \\
\text { cubic feet per } \\
\text { second }\end{array}$ \\
\hline 1 & 196 & 55 & 33 \\
5 & 122 & 60 & 31 \\
10 & 90 & 65 & 28 \\
15 & 76 & 70 & 27 \\
20 & 63 & 75 & 25 \\
25 & 56 & 80 & 23 \\
30 & 49 & 85 & 21 \\
35 & 45 & 90 & 19 \\
40 & 41 & 95 & 16 \\
45 & 38 & 99 & 13 \\
50 & 35 & & \\
\hline
\end{tabular}

Figure 12. Flow-duration curves for August for extended and historical period of record (top), and flow-duration statistics for January based on extended period of record, March 1948 through September 1998 (bottom), for Pleasant River near Epping, Maine. 


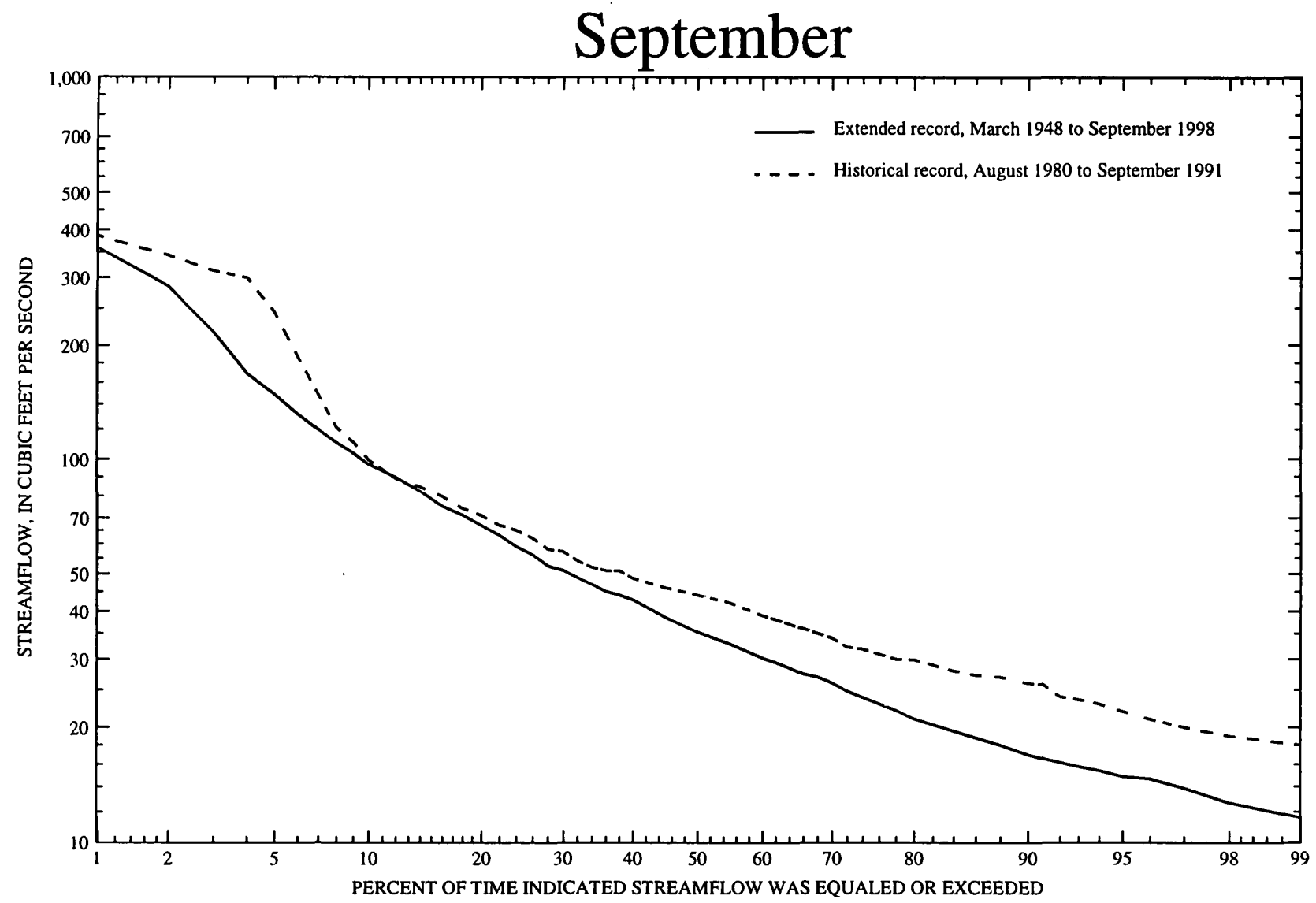

\begin{tabular}{cccc}
\hline $\begin{array}{c}\text { Percent of time } \\
\text { indicated } \\
\text { streamflow was } \\
\text { equaled or } \\
\text { exceeded }\end{array}$ & $\begin{array}{c}\text { Streamflow, in } \\
\text { cubic feet per } \\
\text { second }\end{array}$ & $\begin{array}{c}\text { Percent of time } \\
\text { indicated } \\
\text { streamflow was } \\
\text { equaled or } \\
\text { exceeded }\end{array}$ & $\begin{array}{c}\text { Streamflow, in } \\
\text { cubic feet per } \\
\text { second }\end{array}$ \\
\hline 1 & 358 & 55 & 33 \\
5 & 149 & 60 & 30 \\
10 & 97 & 65 & 28 \\
15 & 79 & 70 & 26 \\
20 & 67 & 75 & 23 \\
25 & 58 & 80 & 21 \\
30 & 51 & 85 & 19 \\
35 & 46 & 90 & 17 \\
40 & 43 & 95 & 15 \\
45 & 39 & 99 & 12 \\
50 & 35 & & \\
\hline
\end{tabular}

Figure 13. Flow-duration curves for September for extended and historical period of record (top), and flow-duration statistics for January based on extended period of record, March 1948 through September 1998 (bottom), for Pleasant River near Epping, Maine. 


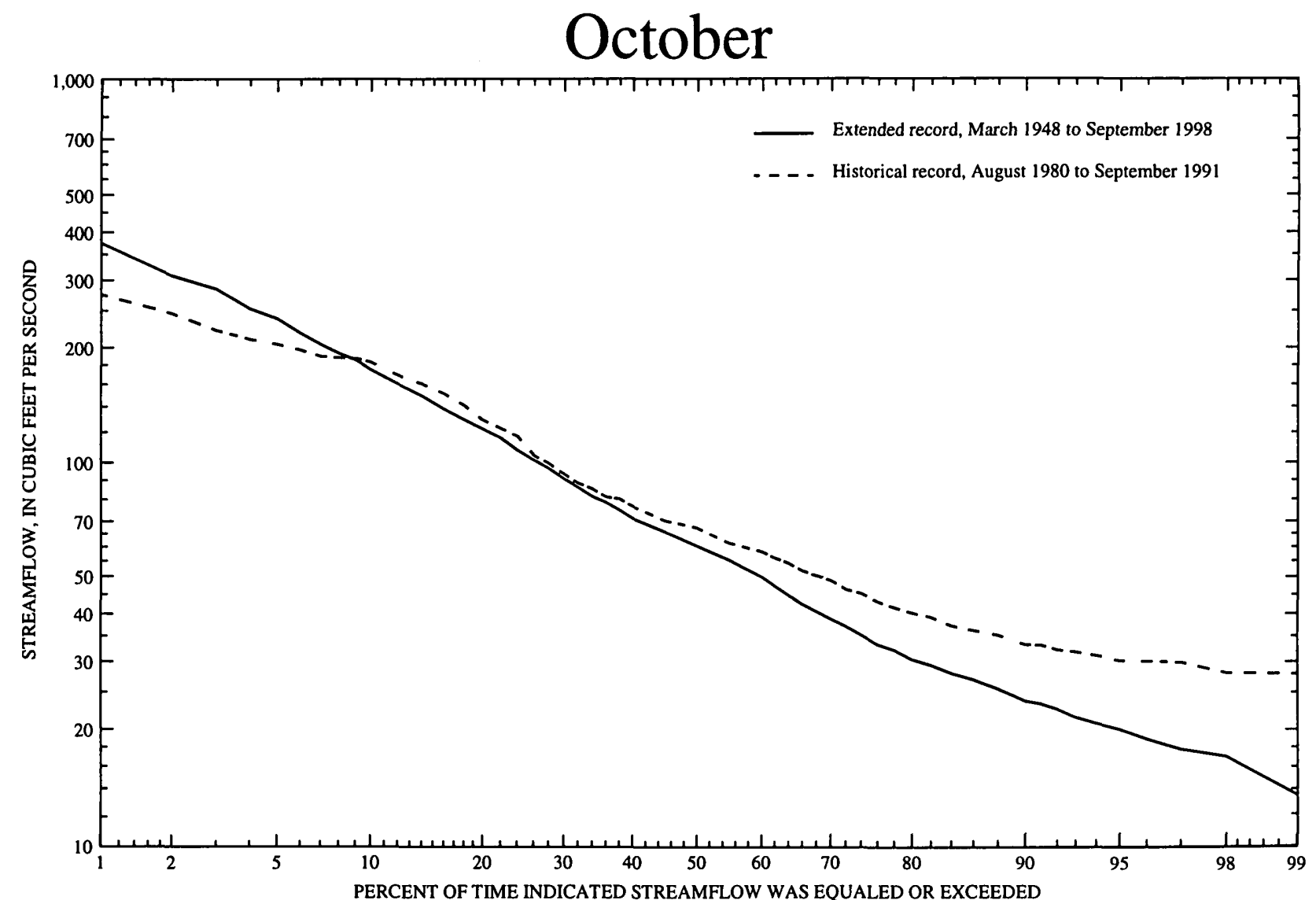

\begin{tabular}{cccc}
\hline $\begin{array}{c}\text { Percent of time } \\
\text { Indicated } \\
\text { streamflow was } \\
\text { equaled or } \\
\text { exceeded }\end{array}$ & $\begin{array}{c}\text { Streamflow, in } \\
\text { cubic feet per } \\
\text { second }\end{array}$ & $\begin{array}{c}\text { Percent of time } \\
\text { indicated } \\
\text { streamflow was } \\
\text { equaled or } \\
\text { exceeded }\end{array}$ & $\begin{array}{c}\text { Streamflow, in } \\
\text { cubic feet per } \\
\text { second }\end{array}$ \\
\hline 1 & 374 & 55 & 55 \\
5 & 238 & 60 & 50 \\
10 & 175 & 65 & 43 \\
15 & 145 & 70 & 39 \\
20 & 122 & 75 & 34 \\
25 & 104 & 80 & 30 \\
30 & 90 & 85 & 27 \\
35 & 80 & 90 & 24 \\
40 & 71 & 95 & 20 \\
45 & 65 & 99 & 13 \\
50 & 60 & & \\
\hline
\end{tabular}

Figure 14. Flow-duration curves for October for extended and historical period of record (top), and flow-duration statistics for January based on extended period of record, March 1948 through September 1998 (bottom), for Pleasant River near Epping, Maine. 


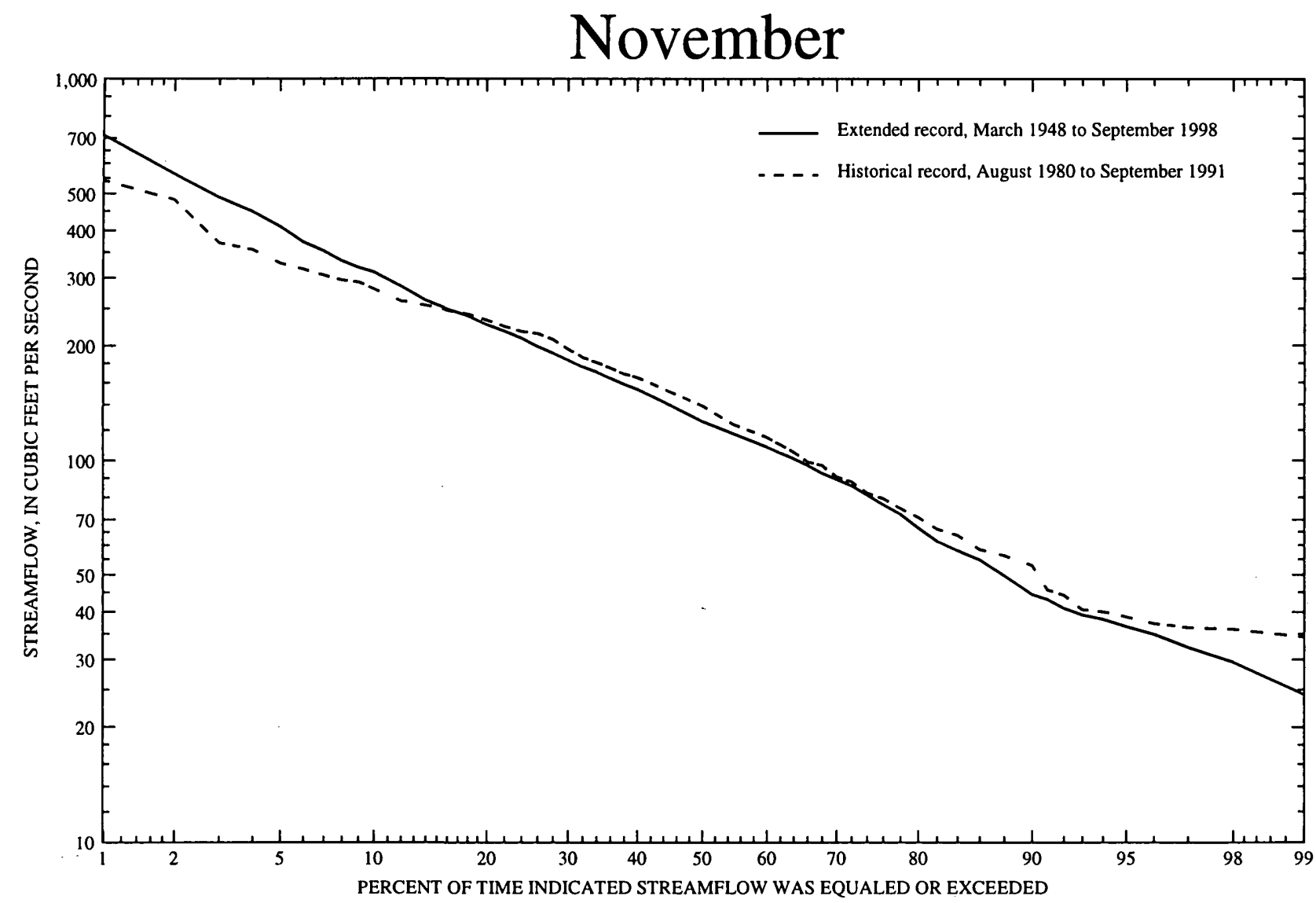

\begin{tabular}{cccc}
\hline $\begin{array}{c}\text { Percent of time } \\
\text { indicated } \\
\text { streamflow was } \\
\text { equaled or } \\
\text { exceeded }\end{array}$ & $\begin{array}{c}\text { Streamflow, in } \\
\text { cubic feet per } \\
\text { second }\end{array}$ & $\begin{array}{c}\text { Percent of time } \\
\text { indicated } \\
\text { streamflow was } \\
\text { equaled or } \\
\text { exceeded }\end{array}$ & $\begin{array}{c}\text { Streamflow, in } \\
\text { cubic feet per } \\
\text { second }\end{array}$ \\
\hline 1 & 711 & 55 & 117 \\
5 & 410 & 60 & 109 \\
10 & 310 & 65 & 99 \\
15 & 253 & 70 & 89 \\
20 & 227 & 75 & 80 \\
25 & 205 & 80 & 67 \\
30 & 183 & 85 & 57 \\
35 & 168 & 90 & 44 \\
40 & 153 & 95 & 37 \\
45 & 140 & 99 & 24 \\
50 & 126 & & \\
\hline
\end{tabular}

Figure 15. Flow-duration curves for November for extended and historical period of record (top), and flow-duration statistics for January based on extended period of record, March 1948 through September 1998 (bottom), for Pleasant River near Epping, Maine. 


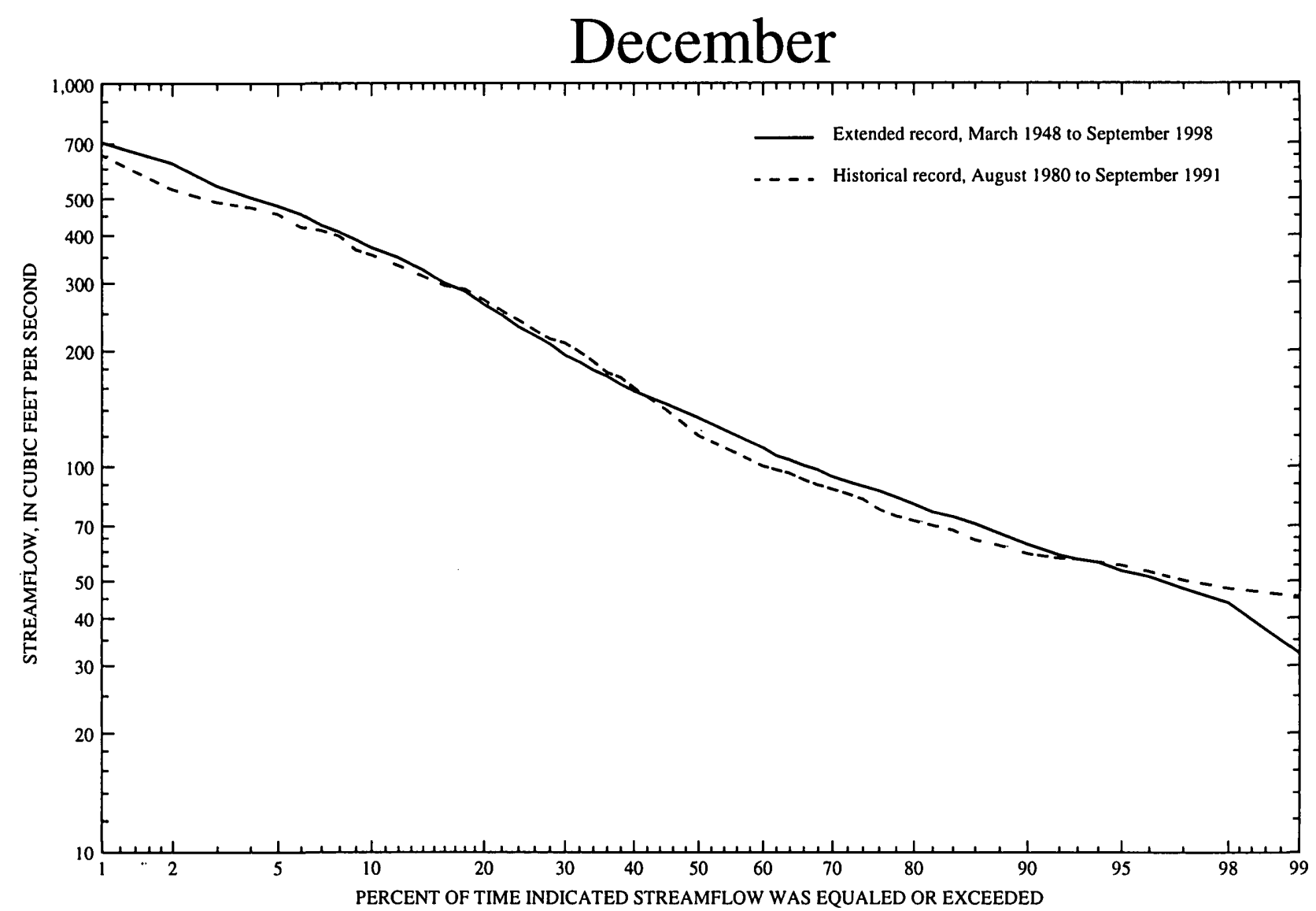

\begin{tabular}{cccc}
\hline $\begin{array}{c}\text { Percent of time } \\
\text { indicated } \\
\text { streamflow was } \\
\text { equaled or } \\
\text { exceeded }\end{array}$ & $\begin{array}{c}\text { Streamflow, in } \\
\text { cubic feet per } \\
\text { second }\end{array}$ & $\begin{array}{c}\text { Percent of time } \\
\text { Indicated } \\
\text { streamflow was } \\
\text { equaled or } \\
\text { exceeded }\end{array}$ & $\begin{array}{c}\text { Streamflow, in } \\
\text { cubic feet per } \\
\text { second }\end{array}$ \\
\hline 1 & 703 & 55 & 122 \\
5 & 478 & 60 & 112 \\
10 & 371 & 65 & 102 \\
15 & 310 & 70 & 94 \\
20 & 263 & 75 & 87 \\
25 & 223 & 80 & 80 \\
30 & 194 & 85 & 72 \\
35 & 175 & 90 & 62 \\
40 & 157 & 95 & 53 \\
45 & 145 & 99 & 32 \\
50 & 134 & & \\
\hline
\end{tabular}

Figure 16. Flow-duration curves for December for extended and historical period of record (top), and flow-duration statistics for January based on extended period of record, March 1948 through September 1998 (bottom), for Pleasant River near Epping, Maine. 


\section{Entire Record}

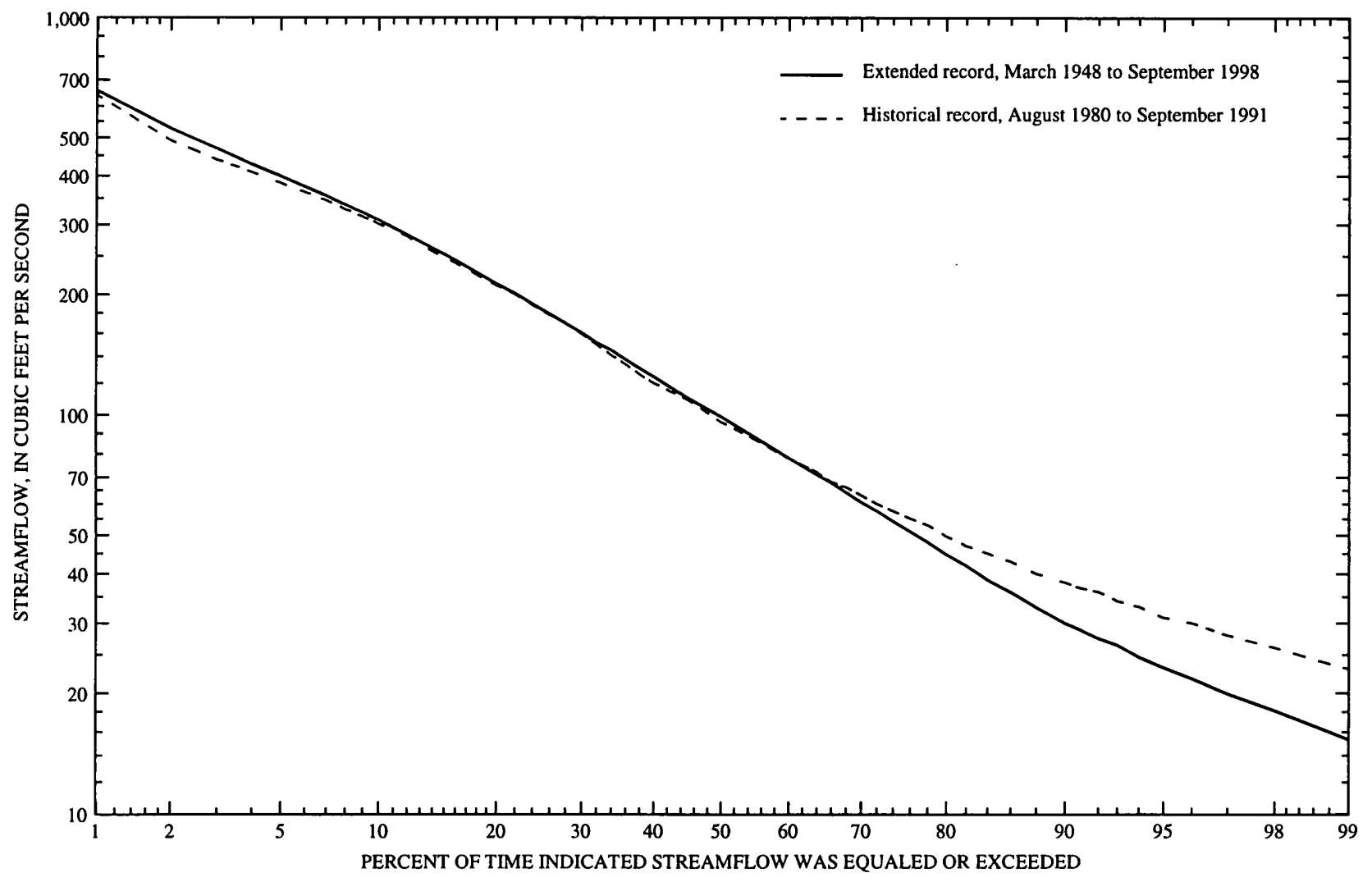

\begin{tabular}{cccc}
\hline $\begin{array}{c}\text { Percent of time } \\
\text { indicated } \\
\text { streamflow was } \\
\text { equaled or } \\
\text { exceeded }\end{array}$ & $\begin{array}{c}\text { Streamflow, in } \\
\text { cubic feet per } \\
\text { second }\end{array}$ & $\begin{array}{c}\text { Percent of time } \\
\text { indicated } \\
\text { streamflow was } \\
\text { equaled or } \\
\text { exceeded }\end{array}$ & $\begin{array}{c}\text { Streamflow, in } \\
\text { cubic feet per } \\
\text { second }\end{array}$ \\
\hline 1 & 656 & 55 & 88 \\
5 & 399 & 60 & 78 \\
10 & 308 & 65 & 70 \\
15 & 252 & 70 & 61 \\
20 & 213 & 75 & 53 \\
25 & 184 & 80 & 45 \\
30 & 160 & 85 & 37 \\
35 & 141 & 90 & 30 \\
40 & 125 & 95 & 23 \\
45 & 110 & 99 & 15 \\
50 & 99 & & \\
\hline
\end{tabular}

Figure 17. Flow-duration curves for extended and historical period of record (top), and flow-duration statistics based on extended period of record, March 1948 through September 1998 (bottom), for Pleasant River near Epping, Maine. 
